\title{
A collagen-binding protein produced by Aeromonas hydrophila
}

\author{
F. ASCENCIO and T. WADSTRÖM*
}

Department of Marine Pathology, Center for Biological Research, La Paz Baja California Sur, CP23000, Mexico and ${ }^{*}$ Department of Medical Microbiology, University of Lund, S-223 62, Lund, Sweden

\begin{abstract}
The gastrointestinal pathogen Aeromonas hydrophila strain A186 produces a collagenbinding protein (CNBP) which is found extracellularly and loosely associated with the cell surface. The cell-associated CNBP was purified by sequential ammonium sulphate precipitation, size-exclusion chromatography and ion-exchange chromatography, or by sequential ammonium sulphate precipitation and affinity chromatography with collagenSepharose. The purified CNBP was homogeneous in SDS-PAGE, and had a mol. wt of $c$. $98 \mathrm{kDa}$. Cyanogen bromide cleavage of the CNBP destroyed collagen-binding activity; however, enzymic digestion with Staphylococcus aureus V8 protease generated $>10$ polypeptide fragments, from which a $30-\mathrm{kDa}$ polypeptide contained the strongest collagen-binding activity. Binding of collagen by the CNBP was restricted to the $\alpha 1$ (I) chain of the collagen molecule and binding seemed to involve both the carbohydrate moieties and certain peptide sequences on the collagen. Collagen-saccharides generated by alkaline hydrolysis inhibited collagen binding by $A$. hydrophila. Also, glycosidase digestion and chemical alteration of the carbohydrate residues of collagen reduced its ability to be bound by the CNBP. Collagen-homologous synthetic peptides inhibited binding of ${ }^{125}$ I-collagen by the bacteria.
\end{abstract}

\section{Introduction}

Collagens, a family of proteins characterised by a triple-helix structure, the repeating Gly-X-Y triplets, and a high content of hydroxyproline and hydroxylysine in its peptide chains [1], display a complex pattern of interactions with different types of cells, with other extracellular matrix components such as fibronectin, laminin and heparan sulphate and with cell receptors called integrins $[2,3]$. Recent studies have shown that several bacterial pathogens bind to various collagens [4-9]. Also, bacterial receptors for collagens and other extracellular matrix components have been proposed as potential virulence factors because of their ability to enhance the adherence of bacterial pathogens to epithelial and endothelial tissues $[6,10,11]$.

Previous studies on the binding of soluble and latex bead-immobilised collagens by the human gastrointestinal pathogen Aeromonas hydrophila have shown that the bacteria recognise fibre-forming collagen type I and basement membrane collagen type IV $[12,13]$.

Received 25 March 1997; revised version accepted 16 Sept. 1997.

Corresponding author: Dr F. Ascencio.
Because of the potential use of adhesins as vaccine candidates against infections produced by $A$. hydrophila and related species in mammals and fish, the current work was carried out to purify and define some biochemical properties of a collagen-binding protein produced by $A$. hydrophila, a pathogen which has become increasingly implicated as a causative agent of human gastroeneteritis and is thought to have an aetiological role in travellers' diarrhoea [14].

\section{Materials and methods}

\section{Chemicals and materials}

Collagen type I (from rat skin), and endo- $\beta$-galactosidase (from Bacteroides fragilis) were purchased from Boehringer Mannheim Scandinavia AB (Bromma, Sweden). Iodobeads (N-chloro-benzenesulphonamidederivatised polystyrene beads) were obtained from Pierce Chemical Co. (Rockford, IL, USA), and ${ }^{125} \mathrm{I}$ from Radiochemical Centre, Amersham, UK. Chromatography media and HPLC columns were purchased from Pharmacia-LKB (Uppsala, Sweden). Peroxidaseconjugated immunoglobulins and 1,2-phenylenediamine (OPD) tablets were from Dakopatts A/S (Glostrup, Denmark). Endoglycosidase F (from Flavobacterium meningosepticum), endoglycosidase $\mathrm{H}$ (from Strepto- 
myces griseus), Vibrio cholerae neuraminidase and the polypeptide mixture (collagen hydrolysates) Polypep ${ }^{\mathrm{R}}$ were purchased from Sigma. Arginine-glycine-aspartic acid (RGD)-containing synthetic peptides were purchased from Telios Pharmaceuticals Inc. (San Diego, CA, USA). The collagen-derived octapeptide H-LysPro-Gly-Glu-Pro-Gly-Pro-Lys-OH was obtained from Nova Biochem (Läufelfingen, Switzerland). Prolinerich protein (PRP-1) was a gift from Dr D. I. Hay (Forsyth Dental Centre, Department of Biochemistry, Boston, MA, USA) and collagen-analogous synthetic peptides were provided by Dr H. Weingarten (Department of Chemistry, Louisiana State University, USA). Culture media and individual culture media ingredients were purchased from Difco (Detroit, MI, USA), except Blood Agar Base No. 1, which was obtained from LabM (London). Immobilon-PVDF membranes were from Millipore (Bedford, MA, USA).

\section{Bacteria and growth conditions}

A. hydrophila strain A186, which was isolated from an infected human patient, is a high binder for collagen type I [13]. Bacterial suspensions were prepared for binding assays by growing them overnight at $32^{\circ} \mathrm{C}$ on blood agar base supplemented with citrated horse blood $4 \%$ (blood agar). Cells were harvested by centrifugation $\left(6000 \mathrm{~g}\right.$ at $4^{\circ} \mathrm{C}$ for $\left.30 \mathrm{~min}\right)$, washed once with $0.02 \mathrm{M}$ potassium phosphate buffer ( $\mathrm{pH} 7.2$ ) containing $0.15 \mathrm{M} \mathrm{NaCl}$ (PBS) and suspended in PBS at a density of $10^{10}$ cells $/ \mathrm{ml}$. For the extraction of cell-associated collagen-binding protein (CNBP), the bacteria were grown in a marine bacteria broth (CIB-4), adjusted to $0.15 \mathrm{M} \mathrm{NaCl}$, as described previously [15].

\section{Assays for collagen binding and inhibition of collagen binding}

Collagen type I (Cn-I) from rat skin was labelled with $0.2 \mathrm{mCi}$ of ${ }^{125} \mathrm{I}$, with Iodobeads to catalyse the reaction [16]. The binding assay was run as described previously [13]. Briefly, $50 \mu \mathrm{l}$ of ${ }^{125} \mathrm{I}$-labelled protein (c. $25000 \mathrm{cpm}$, specificity $1.5 \times 10^{7} \mathrm{cpm} / \mu \mathrm{g}$ ) solution in PBS containing bovine albumin $0.1 \% \mathrm{w} / \mathrm{v}$ were incubated with $100 \mu \mathrm{l}$ of an $A$. hydrophila cell suspension $\left(10^{9}\right.$ cells) in a polystyrene centrifuge tube for $1 \mathrm{~h}$ at $20^{\circ} \mathrm{C}$. After adding $2 \mathrm{ml}$ of ice-cold PBS containing Tween $200.1 \% \mathrm{v} / \mathrm{v}$, the mixtures were centrifuged $\left(4500 \mathrm{~g}\right.$ at $4^{\circ} \mathrm{C}$ for $\left.10 \mathrm{~min}\right)$ and the radioactivity of the pellets was measured in a gamma counter. Incubation mixtures without bacteria were used as background cpm controls and this value was subtracted from the value of the other tubes before the percentage of binding was calculated. The amount of ${ }^{125}$ I-labelled $\mathrm{Cn}-\mathrm{I}$ bound to the bacterial cells was expressed as a percentage of the amount of radiolabelled protein incubated with the $10^{9}$ bacteria. Triplicate determinations were made and the average was determined in all cases.

Binding-inhibition assays were made by incubating bacterial suspensions ( $100 \mu \mathrm{l}$ containing $10^{9}$ cells) at $20^{\circ} \mathrm{C}$ for $1 \mathrm{~h}$ with $100 \mu \mathrm{l}$ of PBS (control), $50 \mu \mathrm{g}$ of unlabelled fragments and $50 \mu \mathrm{g}$ of synthetic peptides, before incubating the bacteria with ${ }^{125} \mathrm{I}-\mathrm{Cn}-\mathrm{I}$. The treated cells were washed with $2 \mathrm{ml}$ of PBS, suspended in $100 \mu \mathrm{l}$ of buffer and used in the binding assay described above. To measure CNBP in fractions or extracts, $100 \mu \mathrm{l}$ of sample were incubated with ${ }^{125} \mathrm{I}$ $\mathrm{Cn}-\mathrm{I}\left(25000 \mathrm{cpm}\right.$ in $50 \mu \mathrm{l}$ of PBS) at $22^{\circ} \mathrm{C}$ for $1 \mathrm{~h}$ before incubation with the bacteria. Inhibition values were calculated as the relative percentage of ${ }^{125} \mathrm{I}-\mathrm{Cn}$-I binding by bacterial cells suspended in PBS without inhibitor and the values extrapolated to calculate the $\mu \mathrm{g}$ of protein required to produce $50 \%$ inhibition of ${ }^{125} \mathrm{I}-\mathrm{Cn}-\mathrm{I}$ binding.

\section{Extraction of cell-associated collagen-binding protein}

A. hydrophila grown in CIB-4 broth and washed with PBS was suspended in water or in various extraction buffers $(0.2 \mathrm{M}$ glycine buffer, $\mathrm{pH} 2.2 ; 3 \mathrm{M}, 4.5 \mathrm{M}$ and $6 \mathrm{M}$ urea; $1 \mathrm{M}$ lithium chloride; sucrose $30 \% \mathrm{w} / \mathrm{v}$ in $50 \mathrm{mM}$ Tris buffer, $\mathrm{pH} 10$; n-octyl- $\beta$-D-glucopyranoside $1 \mathrm{mg} / \mathrm{ml}$; $10 \mathrm{~mm}$ EDTA; PBS, pH 7.2 containing $1 \mathrm{~mm}$ phenylmethylsuphonyl fluoride (PMSF), at a final concentration of $4 \mathrm{~g}$ of cells (wet weight) $/ 100 \mathrm{ml}$ of extraction buffer. Cell suspensions were incubated with gentle stirring at $4^{\circ} \mathrm{C}$ for $30 \mathrm{~min}$ and the bacteria were removed by centrifugation $(12000 \mathrm{~g}$ for $30 \mathrm{~min}$ at $4^{\circ} \mathrm{C}$ ). The supernatant fluids were filtered through a nitrocellulose membrane $(0.45 \mu \mathrm{m})$, dialysed against $0.01 \mathrm{M}$ ammonium bicarbonate and assayed for CNBP activity by determining their ability to inhibit binding of ${ }^{125} \mathrm{I}-\mathrm{Cn}-\mathrm{I}$ (as described above).

\section{Purification of the CNBP}

A. hydrophila PBS extracts were precipitated with ammonium sulphate $\left(60 \%\right.$ saturation at $\left.4^{\circ} \mathrm{C}\right)$. The precipitate was collected by centrifugation $(18000 \mathrm{~g}$ at $4^{\circ} \mathrm{C}$ for $30 \mathrm{~min}$ ), dissolved in distilled water and dialysed exhaustively against $0.01 \mathrm{M}$ ammonium bicarbonate. The solution was lyophilised and kept at $4{ }^{\circ} \mathrm{C}$ until used. The lyophilised preparation was reconstituted in PBS $(30 \mathrm{mg} / \mathrm{ml})$ and filtered $(0.22 \mu \mathrm{m})$ to remove insoluble particles. Five $\mathrm{ml}$ of solution were applied to a Sephacryl S-400 $(100 \times 2.5 \mathrm{~cm})$ chromatographic column (Pharmacia-LKB) equilibrated with the same buffer. The fractions in the major peaks absorbing at $280 \mathrm{~nm}$ were pooled, and the pools (pools 1-3) were assayed for the ability to inhibit binding of ${ }^{125} \mathrm{I}-\mathrm{Cn}-\mathrm{I}$ as described above. The active fractions (pools 2 and 3) were lyophilised.

The CNBP preparation purified by ammonium sulphate precipitation and chromatography with Sephacryl S-400 was reconstituted in $20 \mathrm{mM}$ piperazine buffer, pH $5(1 \mathrm{mg} / \mathrm{ml})$ and $200 \mu \mathrm{l}$ of the solution were loaded on to a Mono $Q \mathrm{H} 5 / 5$ column (Pharmacia-LKB) equilibrated with the same buffer. 
The column was first washed with two bed volumes of equilibrating buffer and then washed with a linear gradient (three bed volumes) of $0-1 \mathrm{M} \mathrm{NaCl}$ in $20 \mathrm{mM}$ piperazine buffer at a flow rate of $1.5 \mathrm{ml} / \mathrm{min}$. The major peak absorbing at $280 \mathrm{~nm}$, which eluted at $c$. $0.45 \mathrm{M} \mathrm{NaCl}$, contained the CNBP. The fractions constituting this peak were pooled and lyophilised.

An alternative purification procedure used to purify the CNBP was affinity chromatography with (Cn-I)AH-Sepharose, with $0.01 \mathrm{M}$ sodium acetate buffer $(\mathrm{pH}$ 5) as equilibrating buffer and CNBP eluted with a 0 $1 \mathrm{M}$ linear gradient of $\mathrm{NaCl}$. CNBP activity was quantified by the $\mathrm{Cn}$-I binding-inhibition assay as described above.

\section{Immunisation}

Adult New Zealand White rabbits were inoculated subcutaneously with highly purified CNBP (30 $\mu \mathrm{g}$ of protein) emulsified in Freund's complete adjuvant (Difco Laboratories). Booster doses of 20-30 $\mu \mathrm{g}$ of protein in Freund's incomplete adjuvant were injected subcutaneously 15 and 30 days later. The rabbits were bled on day 40 and the pooled sera were stored at $-80^{\circ} \mathrm{C}$. Western blot analysis of extracellular proteins and whole-cell lysates of $A$. hydrophila strain A186 showed that the antiserum was specific for the CNBP.

\section{Electrophoresis}

SDS-PAGE was run by the general method of Laemmli [17] with a stacking gel containing acrylamide $4.5 \%$ $\mathrm{w} / \mathrm{v}$ and a separating gel containing acrylamide $12.5 \%$ $\mathrm{w} / \mathrm{v}$. Electrophoresis of the denatured and reduced samples, and of denatured and reduced mol.wt standards (BioRad Laboratories, Richmond, CA, USA) to calibrate the gel was done in a Protean II xi apparatus (BioRad) at $20 \mathrm{~mA}$ (constant current) initially and at $30 \mathrm{~mA}$ after the tracking dye entered the separating gel. The gel was stained with Coomassie Blue R-250.

\section{Western blot analysis}

The separated proteins (under denaturing conditions) were transferred electrophoretically to ImmobilonPVDF membranes, in a semi-dry trans-blot cell, for $2 \mathrm{~h}$ at $200 \mathrm{~mA}$ in $20 \mathrm{mM}$ Tris containing methanol $20 \%$ $\mathrm{v} / \mathrm{v}$ as anodic buffer and $25 \mathrm{mM}$ Tris, $40 \mathrm{mM}$ 6-amino1 -hexanoic acid and methanol $20 \% \mathrm{v} / \mathrm{v}$ as the cationic buffer. Additional binding sites were blocked by incubating the membranes with bovine albumin $3 \%$ $\mathrm{w} / \mathrm{v}$ in $10 \mathrm{mM}$ Tris- $\mathrm{HCl}, 0.15 \mathrm{M} \mathrm{NaCl}(\mathrm{pH} \mathrm{7.2)}$ for $1 \mathrm{~h}$ at $22^{\circ} \mathrm{C}$ and the membranes were washed three times with $10 \mathrm{mM}$ Tris- $\mathrm{HCl}, 0.15 \mathrm{M} \mathrm{NaCl}(\mathrm{pH} \mathrm{7.2)}$ containing Tween-20 (TNT) $0.05 \% \mathrm{w} / \mathrm{v}$. The membranes were probed at $22^{\circ} \mathrm{C}$ for $2 \mathrm{~h}$ with horseradish peroxidase (POD)-labelled Cn-I in $10 \mathrm{mM}$ Tris-HCl, $0.15 \mathrm{M} \mathrm{NaCl}$ (pH 7.2) and after washing three times with TNT, the reactive bands were visualised with 3,3'-diaminobenzidine.

\section{Partial digestion of $C N B P$}

Peptide mapping of the CNBP was done following the general protocol of Cleveland et al. [18]. Polyacrylamide gel slices, containing protein bands excised from the primary gels and equilibrated in $0.125 \mathrm{M}$ Tris- $\mathrm{HCl}$ buffer ( $\mathrm{pH} 6.8$ ) containing SDS $0.1 \% \mathrm{w} / \mathrm{v}$ and $1 \mathrm{mM}$ EDTA (sample buffer), were loaded into the wells of polyacrylamide slab gels containing acrylamide $12.5 \%$ $\mathrm{w} / \mathrm{v}$. The number of slices per well was adjusted to provide a protein of $20-50 \mu \mathrm{g}$. Wells were filled with sample buffer containing glycerol $20 \% \mathrm{v} / \mathrm{v}$, and $25 \mu \mathrm{l}$ of Staphylococcus aureus V8 protease solution ( $25 \mu \mathrm{g} / \mathrm{ml}$ of sample buffer containing glycerol $10 \%$ $\mathrm{v} / \mathrm{v}$ ) was layered on top of the wells containing the gel slices. Electrophoresis and Western blotting were run as described above.

\section{Preparation of collagen $\alpha$-chains, peptides and disaccharides}

Denatured collagen was obtained by heating a Cn-I solution [19]. Cn-I (2-5 mg) dissolved in acetic acid $0.05 \% \mathrm{v} / \mathrm{v}$ was heated at $56^{\circ} \mathrm{C}$ for $60 \mathrm{~min}$, and the $\alpha 1$ (I) and $\alpha 2(\mathrm{I})$ chains were separated by ion-exchange chromatography with CM-cellulose. Cyanogen bromide (CNBr) peptides of $\mathrm{Cn}-\mathrm{I}$ or of the $\alpha 1(\mathrm{I})$-chain were obtained by established procedures [20]. Briefly, collagen preparations $(1-5 \mathrm{mg} / \mathrm{ml})$ were dissolved in formic acid $70 \% \mathrm{v} / \mathrm{v}$, the solutions were flushed with nitrogen and, after addition of a 10-fold excess of $\mathrm{CNBr}(\mathrm{w} / \mathrm{w})$, they were incubated in the dark for $24 \mathrm{~h}$ at $22^{\circ} \mathrm{C}$. Reaction mixtures were then diluted with water to $<5 \%$ formic acid and freeze-dried. $O$ Glycosidic disaccharides (2-O- $\alpha$-D-glucopyranosyl-O$\beta$-D-galactopyranosyl hydroxylysine) were isolated from an alkaline hydrolysate of $\mathrm{Cn}-\mathrm{I}$ as described previously [21].

\section{Binding of glycosidase treated-collagen by $A$. hydrophila}

Glycosidase digestion of collagen. Microwell flatbottom strips (Costar, Cambridge, MA, USA) were coated with Cn-I $10 \mu \mathrm{g} /$ well by incubation at $4^{\circ} \mathrm{C}$ for $16 \mathrm{~h}$ with a solution $(100 \mu \mathrm{l} /$ well $)$ of $\mathrm{Cn}-\mathrm{I}$ in $0.1 \mathrm{M}$ sodium bicarbonate buffer ( $\mathrm{pH} 8.1$ ) containing $0.15 \mathrm{M}$ $\mathrm{NaCl}$. The wells were washed with $10 \mathrm{mM}$ Tris- $\mathrm{HCl}$, $0.15 \mathrm{M} \mathrm{NaCl}(\mathrm{pH} \mathrm{7.2)}$ containing TNT $0.05 \% \mathrm{v} / \mathrm{v}$, and the immobilised collagen was treated with several glycosidases.

$\alpha$-Glucosidase $(0.5 \mathrm{mg} / \mathrm{ml})$ digestion was done in $0.2 \mathrm{M}$ sodium acetate buffer $(\mathrm{pH} 5)$ at $37^{\circ} \mathrm{C}$ for $16 \mathrm{~h}$ [21]. $\beta$-galactosidase $(1 \mathrm{U} / \mathrm{ml})$ digestion was done in $0.1 \mathrm{M}$ sodium citrate buffer $(\mathrm{pH} 4.3)$ and the reaction was run at $37^{\circ} \mathrm{C}$ for $16 \mathrm{~h}$. Neuraminidase $(5 \mathrm{U} / \mathrm{ml})$ treatment was done at $37^{\circ} \mathrm{C}$ for $16 \mathrm{~h}$ in $0.5 \mathrm{M}$ sodium acetate buffer ( $\mathrm{pH} 5.5$ ) containing $4 \mathrm{mM} \mathrm{CaCl}_{2}$. Endo$\beta$-galactosidase $(6 \mathrm{mU} / \mathrm{ml})$ digestion was done at $37^{\circ} \mathrm{C}$ 
for $24 \mathrm{~h}$ in $0.05 \mathrm{M}$ sodium acetate buffer $(\mathrm{pH} 5.8)$ containing bovine albumin $(0.2 \mathrm{mg} / \mathrm{ml})$. Endo- $\beta$-Nacetylglucosaminidase $\mathrm{H}(7 \mathrm{mU} / \mathrm{ml})$ digestion was performed at $37^{\circ} \mathrm{C}$ for $24 \mathrm{~h}$ in $0.025 \mathrm{M}$ sodium acetate buffer ( $\mathrm{pH}$ 5.5). Endo- $\beta$-N-acetylglucosaminidase $\mathrm{F}$ $(1 \mathrm{mU} / \mathrm{ml})$ digestion was performed at $37^{\circ} \mathrm{C}$ for $18 \mathrm{~h}$ in $0.25 \mathrm{M}$ sodium acetate buffer ( $\mathrm{pH} 6.5$ ) containing $20 \mathrm{mM}$ EDTA and $10 \mathrm{~mm} 2-\beta$-mercaptoethanol. Cn-I immobilised on the ELISA plates was also treated with $\mathrm{NaIO}_{4}(0.075 \mathrm{M}), \mathrm{Na}\left(\mathrm{BH}_{4}\right)(0.075 \mathrm{M})$ and $\mathrm{H}_{2} \mathrm{SO}_{4}$ $(0.025 \mathrm{M})$ for $1 \mathrm{~h}$ at $37^{\circ} \mathrm{C}$; plates were washed with PBS and blocked with BSA $3 \% \mathrm{w} / \mathrm{v}$ as described above. All of the enzymic and chemical partial digestions were accompanied by controls containing the enzyme or the substrate separately. At the end of the incubations, plates were washed four times with TNT buffer and collagen binding was assayed as described below.

ELISA procedure for assay of soluble CNBP binding to treated collagen. One hundred $\mu 1$ of PBS containing $10 \mu \mathrm{g}$ of purified CNBP were added to each glycosidase-treated collagen-coated well and the plates were incubated for $1 \mathrm{~h}$ at $37^{\circ} \mathrm{C}$. The wells were washed four times with TNT buffer and $100 \mu 1$ of rabbit polyclonal antibodies raised against purified CNBP (diluted 1 in 500 ) were added to each well. After $2 \mathrm{~h}$, the wells were washed four times with TNT buffer and $100 \mu 1$ of POD-labelled porcine IgG against rabbit IgG (diluted 1 in 1000) were added to each well and incubated at $37^{\circ} \mathrm{C}$ for $90 \mathrm{~min}$. The wells were washed four times with TNT buffer, then the substrate solution $(1 \mathrm{mg}$ of $\mathrm{OPD} / \mathrm{ml}$ of $0.05 \mathrm{M}$ sodium citrate buffer, $\mathrm{pH}$ 5) was added to each well $(100 \mu \mathrm{l} /$ well $)$, the plates were incubated at $22^{\circ} \mathrm{C}$ for $30 \mathrm{~min}$ and the $\mathrm{A}_{492}$ of each well was measured in an ELISA plate reader. The results are expressed as a relative percentage compared to the binding of CNBP to untreated collagen-coated wells.

Radiolabelling procedure for assay of soluble CNBP and cell-associated CNBP binding. One hundred $\mu 1$ of a solution of ${ }^{125}$ I-labelled CNBP $(25000 \mathrm{cpm}$; specific activity $10^{6} \mathrm{cpm} / \mu \mathrm{g}$ ), or $25000 \mathrm{cpm}$ of ${ }^{125}$ I-labelled $A$. hydrophila cells were added to each glycosidase-treated collagen-coated well. After incubation for $1 \mathrm{~h}$ at $37^{\circ} \mathrm{C}$, the wells were washed five times with TNT buffer and the bound radioactivity was counted in a gamma counter. Binding was expressed as the percentage of radioactivity bound to bacteria or CNBP immobilised on to the collagen-coated wells, and where the $100 \%$ end-point was $25000 \mathrm{cpm}$. Background values were corrected for CNBP binding to glycosidase-treated collagen-coated wells $(<10 \%)$.

\section{Results}

\section{Isolation and purification of $C N B P$}

A. hydrophila cell-associated proteins were solubilised by treatment of bacterial cells with water and various extraction solutions. Water, PBS, $\mathrm{LiCl}$, sucrose and $\mathrm{n}$ octyl- $\beta$-D-glucopyranoside yielded extracts with the largest amounts of CNBP activity as revealed by a specific collagen-binding-inhibition assay with ${ }^{125} \mathrm{I}-\mathrm{Cn}$ I as a probe (Table 1).

Based on both the amount of protein extracted from each bacterial treatment, the inhibitory activity on ${ }^{125}$ I-Cn-I binding by $A$. hydrophila cells and the protein purity (extracts composed of a relatively low number of protein bands as revealed by electrophoresis and Western blot analysis), the PBS extraction procedure was used for further isolation and purification of CNBP.

Fractionation of the PBS extracts with ammonium sulphate precipitation gave two fractions, of which the $60 \%$ fraction was found to be most active. Further purification was achieved by sequential size exclusionchromatography with Sephacryl S-400 (Fig. 1a) and ion-exchange chromatography with a Mono Q HR 5/5 column (Fig. 1b), or by affinity chromatography with Cn-I-AH Sepharose (data not shown). Although both purification procedures yielded similar purification

Table 1. Extraction of cell-associated collagen-binding proteins from A. hydrophila strain A186, revealed as inhibition of ${ }^{125} \mathrm{I}-\mathrm{Cn}-\mathrm{I}$ binding to $A$. hydrophila cells

\begin{tabular}{lcc}
\hline Extraction medium & $\begin{array}{c}\text { Protein yield } \\
\text { after extraction } \\
(\mu \mathrm{g} / \mathrm{ml})\end{array}$ & $\begin{array}{c}\text { Protein }(\mu \mathrm{g}) \text { producing } \\
50 \% \text { inhibition of } \\
\text { collagen binding }\end{array}$ \\
\hline $0.2 \mathrm{M}$ Glycine buffer (pH 2.2) & 127 & 56 \\
$1 \mathrm{M} \mathrm{LiCl}(\mathrm{pH} \mathrm{5)}$ & 50 & 6 \\
$6 \mathrm{M}$ Guanidine-HCl & 400 & 32 \\
Sucrose 30\% in 50 mM TRIS buffer (pH 10) & 38 & 6 \\
n-Octyl- $\beta$-D-glucopyranoside (1 mg/ml) & 58 & 8 \\
$3 \mathrm{M}$ Urea & 400 & No inhibition \\
4.5 M Urea & 380 & 104 \\
6 M Urea & 670 & 174 \\
10 mM EDTA & 76 & 69 \\
De-ionised water & 58 & 7 \\
PBS (pH 7.2) & 62 & 11 \\
Culture supernates & 39 & 10 \\
\hline
\end{tabular}

The data represent the means of triplicate measurements and the SD for each mean was $<6 \%$. 
a
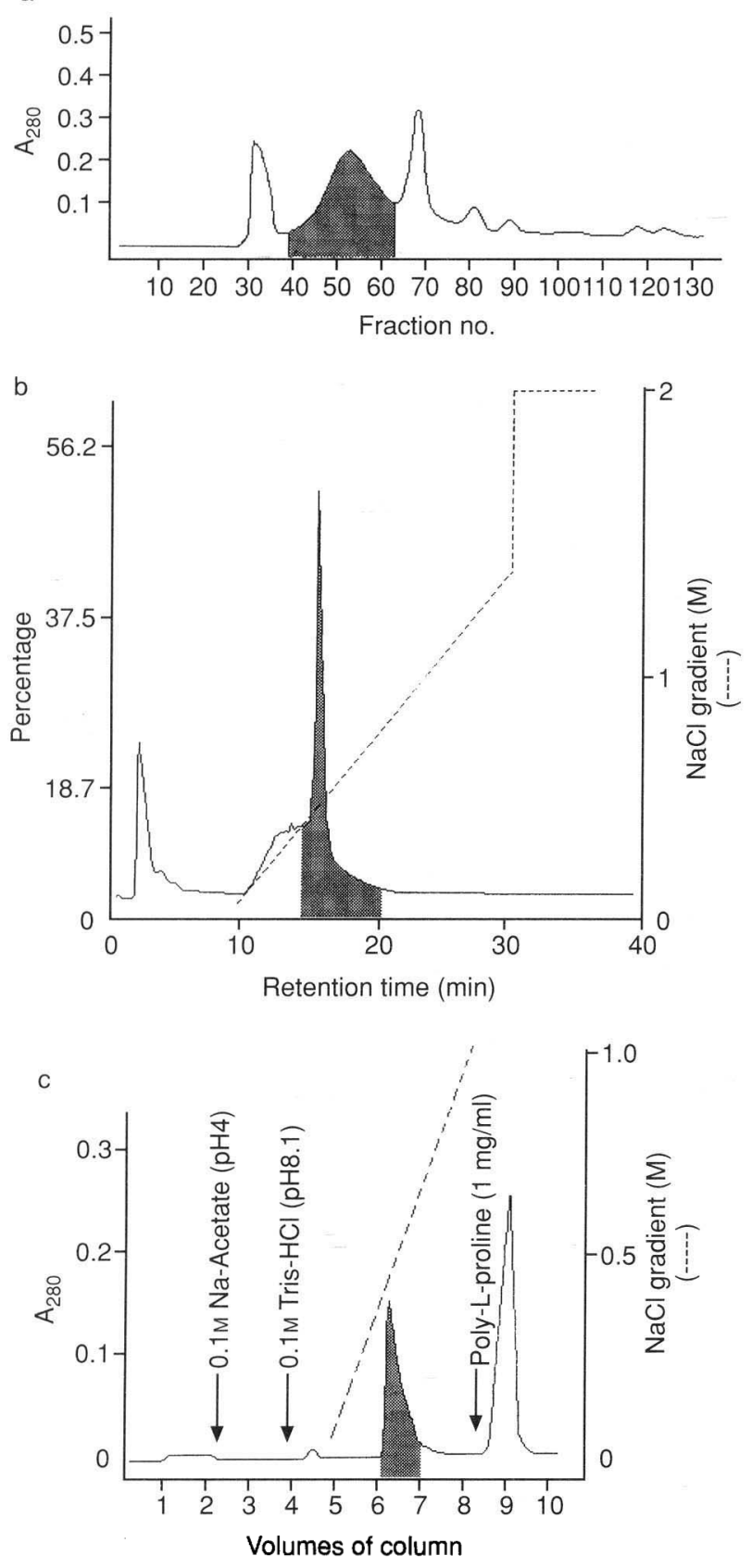

Fig. 1. Chromatographic purification of CNBP produced by $A$. hydrophila strain A186. a, size exclusion chromatography with sephacryl S-400; b, ion-exchange HPLC chromatography with Mono Q HR 5/5 column. c, affinity chromatography with (Cnl)-AH Sepharose. Shadowed peaks indicate fractions containing CNBP detected by its ability to inhibit binding of ${ }^{125} \mathrm{I}-\mathrm{C}$-I $\mathrm{I}$ by $A$. hydrophila. Experimental conditions are described in the Materials and methods section.

results, affinity chromatography was not used further because of its inability to process large amounts of material, its yield of only small amounts of purified CNBP, higher losses of the biological activity of the CNBP and the short life of the chromatographic column. A summary of the purification data is given in Table 2 .

The final purified CNBP preparation was homoge- neous by SDS-PAGE and Western blot analysis, with POD-labelled collagen as a probe (Fig. 3). The analysis indicated that the protein had a mol.wt of c. $98 \mathrm{kDa}$ under reducing conditions.

\section{Partial digestion of the CNBP}

Because one of the goals of these studies with $A$. hydrophila adhesins and lectins concerns their application as potential vaccine candidates, the CNBP was cleaved with $\mathrm{CNBr}$ and $S$. aureus V8 protease to define whether the collagen-binding site(s) are restricted to certain domains in the CNBP molecule, and to determine whether the generation of synthetic peptides homologous to the collagen-binding domains of the CNBP could be an alternative strategy for a vaccine candidate. $\mathrm{CNBr}$ cleavage of the $\mathrm{CNBP}$ gave one main polypeptide of $27 \mathrm{kDa}$ and three minor bands (Fig. 2), but no collagen-binding activity was detected in the Western blot analysis (data not shown). However, proteolytic cleavage of the CNBP with $S$. aureus V8 protease gave $>10$ polypeptide bands. The band corresponding to a mol.wt of $30 \mathrm{kDa}$ showed the strongest collagen-binding activity, as revealed by Western blot analysis (Fig. 3).

\section{Location of the A. hydrophila CNBP binding sites on the Cn-I molecule}

As both the microbial adhesin or the host cell receptor can be used as blocking agents for inhibiting bacterial adherence on to host tissues in anti-adhesive therapies during microbial colonisation and infection, this study evaluated whether the collagen molecule had specific binding sites recognised by the CNBP. Purified $\alpha 1$ (I) and $\alpha 2$ (I) chains, collagen oligosaccharides, collagen peptides generated by $\mathrm{CNBr}$ cleavage and collagen-homologous synthetic peptides $(10 \mu \mathrm{g}$ in $100 \mu \mathrm{l})$ were evaluated for their ability to inhibit ${ }^{125}$ I-collagenbinding by the $A$. hydrophila cells. The $\alpha 1(\mathrm{I})$ chain, but not the $\alpha 2$ (I) chain, significantly inhibited collagen binding (Table 3). In addition, preparations of the carbohydrate moieties of the $\mathrm{Cn}-\mathrm{I}$ also inhibited collagen binding (Table 3). To define better whether the glycosidic residues of the collagen molecule were involved in binding to the $A$. hydrophila CNBP, Cn-I was treated with glycosidases, sodium periodate, sodium borohydride and sulphuric acid. Although some differences were observed in collagen binding depending on the assay method, removal or alteration of the oligosaccharide units of the collagen molecule decreased collagen binding by the $A$. hydrophila CNBP (Table 4).

Studies with peptides generated by $\mathrm{CNBr}$-cleavage and $S$. aureus V8 protease cleavage of $\mathrm{Cn}-\mathrm{I}$, blotted on to PVDF membranes and assayed for binding of purified ${ }^{125}$ I-labelled CNBP, were unsuccessful in identifying the binding domains for the CNBP (data not shown). However, collagen-homologous peptides, proline-rich polypeptides and arginine-glycine-aspartic acid sequences (RGD) were studied for their ability to 
Table 2. Purification of CNBP produced by A. hydrophila strain A186

\begin{tabular}{|c|c|c|c|c|}
\hline Purification stage & $\begin{array}{l}\text { Total protein } \\
(\mathrm{mg})\end{array}$ & $\begin{array}{l}\text { Collagen-binding } \\
\text { inhibition }(\%)\end{array}$ & Specific activity & $\mathrm{x}$-Fold purification \\
\hline 1. PBS extract & 100 & 6 & 28 & 1 \\
\hline 2. $\left(\mathrm{NH}_{4}\right)_{2} \mathrm{SO}_{4}$ preeipitation ( $60 \%$ saturation) & 12.2 & 87 & 36 & 0.6 \\
\hline \multicolumn{5}{|c|}{ 3. Size exclusion chromatography (Sephacryl S-400) } \\
\hline Pool 2 & 2.7 & 90 & 2.0 & 11.5 \\
\hline Pool 3 & 1.2 & 90 & 1.7 & 13.5 \\
\hline 4. Ion-exchange chromatography & 1 & 48 & 13 & 8 \\
\hline
\end{tabular}

* Specific activity is defined as the amount of protein $(\mu \mathrm{g})$ required to produce $50 \%$ inhibition of collagen binding.

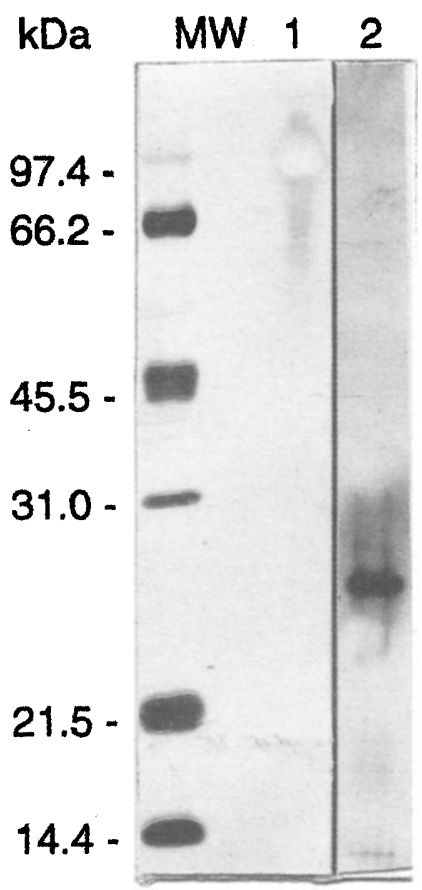

Fig. 2. SDS-PAGE of $A$. hydrophila strain A186 CNBP and its $\mathrm{CNBr}$-cleavage-generated fragments. Lane 1, CNBP; 2, CNBr-cleaved CNBP. Mol.wt standards (MW) were lysozyme, 14400; soybean trypsin inhibitor, 21500 ; bovine carbonic anhydrase, 31000 ; ovalbulmin, 45000 ; bovine albumin, 66200 ; rabbit muscle phosphorylase B, 97400 .

inhibit collagen binding. Neither proline-rich polypeptides nor the RGD sequences interfered in the collagen-binding process significantly, but some collagen-homologous peptides, containing a Gly-X-Y collagen triplet, inhibited collagen binding by $A$. hydrophila cells (Table 5).

\section{Discussion}

It is now generally accepted that, during the course of an infectious disease, bacteria colonise body sites by sequentially meshing their surface-bound adhesins with cognate receptors available on epithelial cells, endothelial cells, or with extracellular matrix components [22] The production of collagen-binding surface proteins by gram-positive and gram-negative bacterial pathogens has been addressed in a number of publications [4-9]. The present studies indicate that the human gastrointestinal pathogen $A$. hydrophila, previously found to have a high affinity for collagen types I and IV [3], expresses a collagen-binding protein (CNBP) loosely associated with cells. Cell-surface extracts and culture supernates of $A$. hydrophila strain A186 contain CNBP(s) that competitively inhibits binding of collagen by the bacteria. Western blot analysis was used to determine whether the $98-\mathrm{kDa}$ protein purified from the supernatant fluids was the same as the cell-associated CNBP, or represented another protein of similar mol.wt. Peroxidase-labelled collagen and rabbit antisera specific for the $98-\mathrm{kDa}$ protein chromatographically purified from the bacterial cell surface recognised the $98-\mathrm{kDa}$ CNBP (data not shown).

In the chromatographic procedures used to purify the A. hydrophila CNBP, an increase in the specific activity of the CNBP preparation was achieved, but some of its biological activity was lost as revealed by the $\mathrm{x}$-fold purification (Table 2). A possible explanation could be that the ionic strength and $\mathrm{pH}$ of the buffers employed in the chromatographic procedures affected the stereochemical conformation of the CNBP, especially the affinity chromatographic procedure. For this reason, this last purification stage was omitted from further studies.

Although the receptor chosen necessarily restricts the possible fate of the bound pathogen, according to Hoepelman and Tuomanen [22] virtually every pathogen has more than one adhesin, thereby conferring the capability to interact with more than one cell receptor. In that regard, $A$. hydrophila has been reported to produce several adhesins and haemagglutinins [2326]. Several lines of evidence indicate that the chromatographically purified $98-\mathrm{kDa} \mathrm{CNBP}$ binds to $\mathrm{Cn}-\mathrm{I}$ in more than one manner, i.e., through some polypeptide sequences of $\mathrm{Cn}-\mathrm{I}$, and by the interaction of lectin-like CNBP domains with glycosidic residues in Cn-I. Removal or alteration of the carbohydrate residues in $\mathrm{Cn}-\mathrm{I}$, by enzymic or chemical methods, decreased collagen binding. Single monosaccharide precursors of the collagen disaccharide moieties (galactose and glucose) did not inhibit collagen binding [13]. However, the O-glycosidic branches of the collagen molecule, isolated by alkaline hydrolysis, 
a

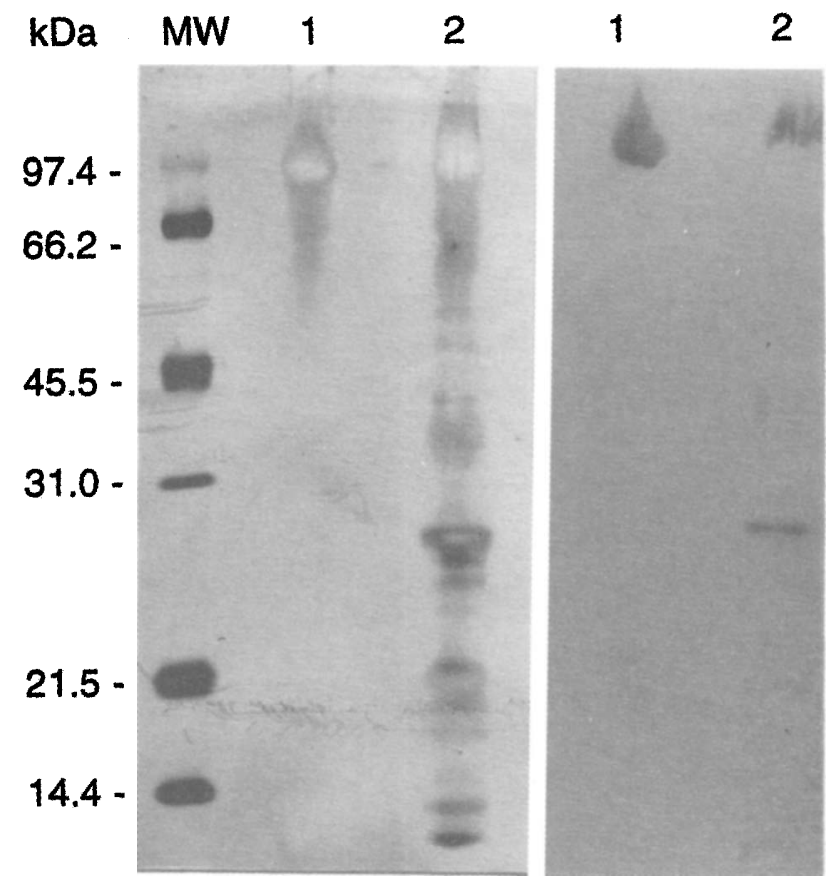

Fig. 3. Enzymic cleavage of CNBP from $A$. hydrophila. a, SDS-PAGE stained with Coomassie Blue R-250; b, Western blot analysis with peroxidase-labelled Cn-I. Lane 1, purified CNBP; 2, CNBP partially digested with $S$. aureus V8 protease. Mol.wt standards (MW) were as described for Fig. 2.

Table 3. Inhibition of ${ }^{125} \mathrm{I}-\mathrm{Cn}-\mathrm{I}$ binding to $A$. hydrophila $\mathrm{A} 186$ by $\mathrm{Cn}-\mathrm{I}$ polypeptides and $\mathrm{Cn}-\mathrm{I}$ saccharides

\begin{tabular}{lc}
\hline Collagen preparation & $\begin{array}{c}\text { Collagen-binding inhibition } \\
(\%)\end{array}$ \\
\hline Whole Cn-I molecule & 70 \\
$\alpha 1(1)$ chain & 45 \\
$\alpha 2(1)$ chain & 0 \\
CNBr-cleaved Cn-I & 40 \\
CNBr-cleaved $\alpha 1(1)$ chain & 10 \\
Saccharide residues (2-O- $\alpha$-D-glucopyranosyl-O- $\beta$-D- & 10 \\
galactopyranosylhydroxylysine) & 19 \\
Polyprep & \\
\hline
\end{tabular}

The data represent the means of triplicate measurements and the SD for each mean was $<6 \%$.

inhibited binding of collagen by the bacterium. Also, collagen-homologous peptide(s), but not RGD-containing sequences or proline-rich polypeptides, inhibited collagen binding.

Inhibition of collagen binding by collagen-homologous synthetic peptides has also been observed in studies with $S$. aureus and Escherichia coli $[6,11]$. The importance of the collagen glycosidic moieties has not been addressed in the interactions of these pathogens with collagen, except in the case of binding of type IV collagen by uropathogenic $E$. coli strains. In that case, it was shown that binding does not involve lectin-like interactions [10].

Although CNBr-cleaved collagen inhibits collagen binding by $A$. hydrophila and $S$. aureus, the CNBP of $A$. hydrophila differs from the $S$. aureus CNBP [6] and $E$. coli CNBP [11] in being strongly inhibited only by the $\alpha 1$ (I) collagen chain. Attempts to define which CNBr-generated polypeptide is recognised by the $A$. hydrophila CNBP by Western blot analysis with ${ }^{125}$ I-labelled CNBP were unsuccessful. The iodination procedure used appears to have destroyed the biological activity of the CNBP (data not shown).

Treatment of the purified CNBP with $S$. aureus V8 protease generated several polypeptides of different size, as revealed by electrophoretic analysis, but the collagen-binding domain was restricted to a polypeptide chain of $c$. $30 \mathrm{kDa}$, as revealed by Western blot analysis with peroxidase-labelled collagen as a probe. Conversely, $\mathrm{CNBr}$ cleavage of the CNBP generated a major polypeptide of $c .45 \mathrm{kDa}$ that did not recognise 
Table 4. Effect of glycosidase digestion of collagen type I for binding by $A$. hydrophila strain A186 and by its soluble CNBP

\begin{tabular}{|c|c|c|c|}
\hline \multirow[b]{2}{*}{ Collagen treatment } & \multicolumn{3}{|c|}{$\begin{array}{c}\text { Percentage binding of glycosidase-treated } \\
\text { collagen to }\end{array}$} \\
\hline & $\begin{array}{c}{ }^{125} \text { I-labelled } \\
\text { bacteria }\end{array}$ & $\begin{array}{l}{ }^{125} \text { I-labelled } \\
\text { CNBP }\end{array}$ & $\begin{array}{l}\text { unlabelled } \\
\text { CNBP }\end{array}$ \\
\hline Control (PBS) & 0 & 0 & 0 \\
\hline \multicolumn{4}{|l|}{ Endo-glycosidase } \\
\hline Endo- $\beta$-galactosidase & 10 & 34 & 14 \\
\hline Endo-glycosidase $\mathrm{F}$ & 20 & 36 & ND \\
\hline Endo-glycosidase $\mathrm{H}$ & 28 & 27 & ND \\
\hline \multicolumn{4}{|l|}{ Exo-glycosidase } \\
\hline$\beta$-galactosidase & 33 & 52 & 23 \\
\hline$\alpha$-glucosidase & 34 & 66 & 0 \\
\hline Neuraminidase & 38 & 50 & 0 \\
\hline \multicolumn{4}{|l|}{ Chemical agent } \\
\hline $\mathrm{NaIO}_{4}$ & 47 & 54 & 0 \\
\hline $\mathrm{Na}\left(\mathrm{BH}_{4}\right)$ & 29 & 60 & 6 \\
\hline $\mathrm{H}_{2} \mathrm{SO}_{4}$ & 43 & 9 & 0 \\
\hline
\end{tabular}

ND, not done.

The data represent the means of triplicate measurements and the SD for each mean was $<6 \%$.

Table 5. Inhibition of binding of ${ }^{125} \mathrm{I}-\mathrm{Cn}-\mathrm{I}$ to $A$. hydrophila A186 by synthetic peptides

\begin{tabular}{lc}
\hline Peptide sequence & $\begin{array}{c}\text { Collagen-binding } \\
\text { inhibition (\%) }\end{array}$ \\
\hline Collagen-homologous peptides & \\
Pz-Pro-Leu-Gly-Pro-D-Arg-OH & 0 \\
Ac-Gly-Pro-Leu-Gly-Ile-Ala-OC ${ }_{2} \mathrm{H}_{5}$ & 22 \\
Ac-Leu-Leu-Gly-Ile-Leu-OH & 0 \\
Ac-Pro-Leu-Gly-Leu-Leu-Gly-OC ${ }_{2} \mathrm{H}_{5}$ & 70 \\
Ac-Ala-Leu-Gly-Leu-Ala-Gly-OH & 0 \\
H-Lys-Pro-Gly-Glu-Pro-Gly-Pro-Lys-OH & 0 \\
RGD sequences & \\
H-Gly-Arg-Gly-Asp-OH & 7 \\
H-Gly-Arg-Gly-Asp-Ser-OH & 2 \\
n-Me-Gly-Arg-Gly-Asp-Ser-Pro & 7 \\
Gd-Arg-Gly-Asp-Ser-Pro-Ala-Ser-Ser-Lys & 0 \\
Proline-rich polypeptides & \\
PRP-1 & 0 \\
Poly-L-proline (mol. wt 7600) & 0 \\
\hline
\end{tabular}

The data represent the means of triplicate measurements and the SD for each mean was $<6 \%$.

peroxidase-labelled collagen, thus indicating that the biological activity of the CNBP was destroyed by $\mathrm{CNBr}$ cleavage.

Recently, Kostrzynska et al. [27] reported on the antigenic diversity of two structural domains in the Slayer protein of $A$. hydrophila TF7. Further studies will be needed to determine if this antigenic diversity is also reflected in the $A$. hydrophila CNBP epitope that has the collagen-binding domain and might be useful for vaccine development.

As adhesion factors are most important in the early stages of an infection process, for the adhesion, colonisation and establishment of the pathogen in a host, the possibility of using adhesins and lectins as vaccine candidates is attractive. Ongoing studies in this laboratory are focused on the use of $A$. hydrophila antigen as immunogenic and immunoprotective agents against infections produced by $A$. hydrophila and related species in marine fish. Antigens from $A$. hydrophila with affinity for mucosal constituents and collagenous proteins have recently been found to stimulate the mucosal immune system of rabbit [28] and fish (unpublished results), and are considered as vaccine candidates for $A$. hydrophila infections in fish farming.

This study was supported by grants from the Swedish Medical Research Council (16X04723), from the Medical Faculty of the University of Lund, and from the Royal Physiographic Society, Lund, Sweden. We thank Dr E. Glazier for editing the English version of the manuscript.

\section{References}

1. Martin GR, Timpl R, Müller PK, Kühn K. The genetically distinct collagens. TIBS 1985; 10: $285-287$.

2. Miller EJ, Gay S. The collagens: an overview and update. In: Cunningham LW (ed) Methods in enzymology, vol 144. Structural and contractile proteins; part D - Extracellular matrix. Orlando FL, Academic Press. 1987: 3-41.

3. Gullberg D, Terracio L, Borg TK, Rubin K. Identification of integrin-like matrix receptors with affinity for interstitial collagens. J Biol Chem 1989; 264: 12686-12694.

4. Fitzgerald TJ, Repesh L, Blanco DR, Miller JN. Attachment of Treponema pallidum to fibronectin, laminin, collagen IV and collagen I, and blockage of attachment by immune rabbit IgG. Br J Vener Dis 1984; 60: 357-363.

5. Vercellotti GM, McCarthy JB, Lindholm P, Peterson PK, Jacob HS, Furcht LT. Extracellular matrix proteins (fibronectin, laminin, and type IV collagen) bind and aggregate bacteria. Am J Pathol 1985; 120: 13-21.

6. Speziale P, Raucci G, Visai L, Świtalski LM, Timpl R, Höök M. Binding of collagen to Staphylococcus aureus Cowan 1. $J$ Bacteriol 1986; 167: 77-81.

7. Winkler JR, John SR, Kramer RH, Hoover CI, Murray PA. Attachment of oral bacteria to a basement-membrane-like matrix and to purified matrix proteins. Infect Immun 1987; 55: $2721-2726$.

8. Kostrzynska M, Schalén C, Wadström T. Specific binding of collagen type IV to Streptococcus pyogenes. FEMS Microbiol Lett 1989; 59: 229-234.

9. Tarkkanen A-M, Allen BL, Westerlund B et al. Type V collagen as the target for type-3 fimbria, enterobacterial adherence organelles. Mol Microbiol 1990; 4: 1353-1361.

10. Westerlund B, Kuusela P, Risteli J et al. The 075X adhesin of uropathogenic Escherichia coli is a type IV collagen-binding protein. Mol Microbiol 1989; 3: 329-337.

11. Visai L, Speciale P, Bozzini S. Binding of collagens to an enterotoxigenic strain of Escherichia coli. Infect Immun 1990; 58: $449-455$

12. Ascencio F, Aleljung P, Olusanya O, Wadström T. Type I and IV collagen and fibronectin binding to Aeromonas species isolated from various infections. Int J Med Microbiol 1990; 273: $186-194$.

13. Ascencio F, Ljungh $\AA$, Wadström T. Comparative study of extracellular matrix protein binding to Aeromonas hydrophila isolated from diseased fish and human infection. Microbios 1991; 65: $135-146$.

14. Hänninen ML, Salmi S, Mattila L, Taipalinen R, Siitonen A. Association of Aeromonas spp. with travellers' diarrhoea in Finland. $J$ Med Microbiol 1995; 42: 26--31.

15. Ascencio-Valle F, Lopez-Cortes A, Ochoa J-L. Differences in cell surface hydrophobicity of pigmented halobacteria and corresponding achromatic strains evidenced by adsorption onto phenyl-sepharose. Microbios Lett 1984; 37: 131-135.

16. Markwell MAK. A new solid state-reagent to iodinate proteins. 1. Conditions for the efficient labeling of antiserum. Anal Biochem 1982; 125: 427-432.

17. Laemmli UK. Cleavage of structural proteins during the assembly of the head of bacteriophage T4. Nature 1970; 227: 680-685.

18. Cleveland DW, Fischer SG, Kirschner MW, Laemmli UK. 
Peptide mapping by limited proteolysis in sodium dodecyl sulfate and analysis by gel electropheresis. J Biol Chem 1977; 252: $1102-1106$.

19. Dessau W, Adelmann BC, Timpl R, Martin GR. Identification of the sites in collagen alpha-chains that bind serum antigelatin factor (cold-insoluble globulin). Biochem $J$ 1978; 169: $55-59$.

20. Timpl RP, Bruckner P, Fietzek P. Characterization of pepsin fragments of basement membrane collagen obtained from a mouse tumor. Eur J Biochem 1979; 95: 255-263.

21. Spiro RG. The structure of the disaccharide unit of the renal glomerular basement membrane. J Biol Chem 1967; 242: $4813-4823$.

22. Hoepelmann AI, Tuomanen EI. Consequences of microbial attachment: directing host cells functions with adhesins. Infect Immun 1992; 60: 1729-1733.

23. Atkinson HM, Trust TJ. Hemagglutination properties and adherence ability of Aeromonas hydrophila. Infect Immun 1980; 27: 938-946.
24. Burke F, Cooper M, Robinson J et al. Haemagglutination patterns of Aeromonas spp. in relation to biotype and source. $J$ Clin Microbiol 1984; 19: 39-43.

25. Adams D, Atkinson HM, Woods WH. Aeromonas hydrophila typing scheme based on patterns of agglutination with erythrocytes and yeast cells. J Clin Microbiol 1983; 17: 422-427.

26. Stewart GA, Bundell CS, Burke V. Partial characterisation of a soluble haemagglutinin from human diarrhoeal isolates of Aeromonas. J Med Microbiol 1986; 21: 319-324.

27. Kostrzynska M, Dooley JSG, Shimojo T, Sakata T, .Trust TJ. Antigenic diversity of the S-layer proteins from pathogenic strains of Aeromonas hydrophila and Aeromonas veronii biotype sobria. J Bacteriol 1992; 174: 40-47.

28. Ascencio F, Sierra A, Ruiz-Bustos E, Romero MJ, Greene A, Wadström T. Lectin from Aeromons hydrophila with affinity for mucosal constituents: a possible putative antigen for developing a mucosal vaccine against $A$. hydrophila infections. $J$ Mar Biotechnol 1995; 3: 179-181. 